OPEN ACCESS

Edited by:

Michael Sweet,

University of Derby, United Kingdom

Reviewed by:

Aldo Cróquer,

Simón Bolívar University, Venezuela

Charles Birkeland,

University of Hawaii, United States

*Correspondence:

Elizabeth A. Goergen

liz.goergen@gmail.com

Specialty section:

This article was submitted to

Coral Reef Research,

a section of the journal

Frontiers in Marine Science

Received: 30 April 2018

Accepted: 22 January 2019

Published: 12 February 2019

Citation:

Goergen EA, Moulding AL, Walker BK and Gilliam DS (2019) Identifying Causes of Temporal Changes in Acropora cervicornis

Populations and the Potential

for Recovery. Front. Mar. Sci. 6:36.

doi: 10.3389/fmars.2019.00036

\section{Identifying Causes of Temporal Changes in Acropora cervicornis Populations and the Potential for Recovery}

\author{
Elizabeth A. Goergen*, Alison L. Moulding, Brian K. Walker and David S. Gilliam
}

Halmos College of Natural Sciences and Oceanography, Nova Southeastern University, Dania Beach, FL, United States

Corals, specifically the Atlantic staghorn coral, Acropora cervicornis, are under major threat as disturbance events such as storms and disease and predation outbreaks increase in frequency. Since its population declines due to a wide spread disease event in the early 1980s, limited long-term monitoring studies describing the impact of current threats and potential recovery have been completed. The aim of this study was to document the impacts of environmental (tropical storms, increased wind) and biological (disease and predation) threats on $A$. cervicornis to further understand its population dynamics and potential for recovery. Two high-density $A$. cervicornis patches (greater than 1 hectare each) were surveyed tri-annually (winter, summer, fall) from 2008-2016. A. cervicornis percent cover, canopy height, census of individuals, and prevalence and occurrence of disease, predation, and bleaching were evaluated within permanent $3.5 \mathrm{~m}$ radial plots $(n=27$ and 31 ). Temporal variability was observed in mean percent live cover at both patches and showed an overall loss of tissue. Frequent disturbances such as tropical storms, hurricanes, and disease events, caused increased, prolonged, and widespread mortality. Periods void of disturbance allowed for recovery and growth. Prevalence and occurrence of disease and predation were highly variable between monitoring events. They were also found to be significantly higher on masses (individuals $\geq 1.5 \mathrm{~m}$ ) than on colonies and during summer surveys (JuneAugust). These data indicate that substantial length of time between major disturbance events is necessary for recovery and growth of this species. The implication of these results is that given the current rates of growth, recruitment, and storm frequency, natural species recovery is unlikely unless large scale issues like climate change and ocean warming, which affect the intensity and frequency of disease and predation, are addressed.

Keywords: demographic monitoring, time series, disease, fireworm, long-term monitoring, Florida

\section{INTRODUCTION}

Acropora cervicornis is a fragile, vulnerable, and dynamic species that has been known to change in abundance and/or cover quickly (e.g., weeks to years) in response to disease outbreaks, tropical disturbances, or climatic events (Shinn, 1976; Antonius, 1977; Davis, 1982; Knowlton et al., 1990; Schopmeyer et al., 2012; Miller et al., 2014a) and was frequently found lining the fore reef of many Caribbean, Florida, and Gulf of Mexico coral reefs. Its fast growth rate and ability to reproduce 
asexually allow it to propagate quickly across a site, forming mainly monotypic stands referred to as thickets, fields, stands, or patches (Davis, 1982; Bruckner, 2002; Acropora Biological Review Team, 2005). A. cervicornis plays a significant role in the coral reef community by contributing to reef complexity and habitat framework (Goreau, 1959; Goreau and Goreau, 1973; Adey and Burke, 1977; Neigell and Avise, 1983). The habitat diversity and ecological benefits provided by the structure of $A$. cervicornis colonies are virtually irreplaceable within the natural marine community.

Acropora cervicornis populations became spatially and regionally isolated following a multi-decadal white band disease outbreak starting in the 1970s which left the surviving populations most commonly distributed as individual colonies or much smaller patches (Gladfelter, 1982; Bythell et al., 1989, 1993; Aronson and Precht, 2001; Acropora Biological Review Team, 2005). This dramatic decline leads to its listing as threatened under the United States Endangered Species Act (US ESA; National Marine Fisheries Service, 2006) and as critically endangered on the International Union for Conservation of Nature (IUCN) Red List of Threatened Species (Aronson et al., 2008). Since this dramatic decline, recovery has been limited with few known high cover populations remaining throughout the species' range (Vargas-Ángel et al., 2003; Keck et al., 2005; Grober-Dunsmore et al., 2006; Lirman et al., 2010; Walker et al., 2012; Busch et al., 2016). One region where numerous large patches of $A$. cervicornis exist today is within the Southeast Florida Coral Reef Ecosystem Conservation Area and more specifically in Broward County, FL, at the northern-most extent of this species' range (Vargas-Ángel et al., 2003; Walker et al., 2012; D’Antonio et al., 2016).

However, few data exist on the temporal and spatial variability of the demography and ecology of A. cervicornis (MercadoMolina et al., 2015; Goergen et al., unpublished), and we are only beginning to define the impact disease and predation have on the persistence of this species outside of large scale catastrophic events (Williams and Miller, 2006; Miller et al., 2014a,b; Goergen et al., unpublished). To fully understand the population dynamics of this threatened species and to further inform restoration and conservation efforts, these data need to be evaluated over the long-term.

To address these questions, two semi-continuous patches of A. cervicornis ( $>1$ hectare each) were used to evaluate temporal patterns in species abundance, percent cover, and the presence, prevalence, and occurrence of disease, predation, and bleaching. These analyses will be the first of its kind for this species, which further our understanding of the dynamics of the threats affecting remaining, future, and restored populations.

\section{MATERIALS AND METHODS}

Two large semi-continuous patches of A. cervicornis, BCA and Scooter, formally known as Dave and Oakland I patches, respectively (Vargas-Ángel et al., 2003), were surveyed three times per year during Winter [(WS) February/March], Summer [(SM) June-August], and Fall [(F) October/November] from
Summer 2008 through Fall 2016. These monitoring periods will be referenced by the season followed by the last two digits of the year throughout the rest of this paper (e.g., SM09 is Summer 2009). An additional survey was completed 10 September 2012, following the passing of Tropical Storm Isaac (TSI12) on 26 August 2012. Prior to the initial survey (June 2008), the boundary of each patch was mapped using a handheld GPS. Plots were installed in a grid with spacing appropriate to cover the patch and the surrounding area to account for possible patch growth or movement (Walker et al., 2012). Thirty-two plots each separated by $30 \mathrm{~m}$ were installed at BCA, and 31 plots were installed at Scooter with $23 \mathrm{~m}$ separation.

Monitoring methodologies were modified from a previously developed Acropora spp. demographic monitoring protocol (Williams et al., 2006). Radial plots $7 \mathrm{~m}$ in diameter $\left(38.48 \mathrm{~m}^{2}\right.$ ), marked by a permanent center pin and tag designated the survey area. Temporary transect lines, $7 \mathrm{~m}$ in length were laid perpendicular to each other across the center of each plot defining the survey area during monitoring events. Condition characteristics and a species census were completed in all plots. Condition characteristic data included: (1) estimates of percent cover of live A. cervicornis, (2) the presence and relative ranking of tissue loss caused by white band disease, rapid tissue loss (Williams and Miller, 2005), and predation by the bearded fireworm (Hermodice carunculata), three-spot damselfish (Stegastes planifrons), and the corallivorous snail (Coralliophila abbreviata), and (3) presence and severity of bleaching. Maximum A. cervicornis canopy height was measured within the plot boundary. During the species census, all A. cervicornis individuals were counted and categorized as either a loose fragment, colony [well defined boundary of continuous skeleton (dead or alive), attached, $<1.5 \mathrm{~m}$ diameter] or a mass (difficult to define boundary, typically $>1.5 \mathrm{~m}$ in diameter). Beginning in F10, individuals that showed signs of disease were quantified to obtain disease prevalence of colonies and masses. Presence of disease was not quantified on loose fragments because the cause of recent mortality on fragments could not be identified confidently. All individual areas (occurrences) of recent mortality within the plot boundary were counted based on cause (rapid tissue loss, white band disease, fireworm, and snail); recently dead areas separated by living tissue were counted as separate occurrences. The occurrence of damselfish predation and bleaching were not recorded because of the difficulty in defining and enumerating individual gardens and areas of bleaching.

Meteorological data were obtained from multiple online resources to better describe the conditions during tropical disturbances and aiding in identifying other causal events. Storm track, wind swath data, and individual storm reports were downloaded from the National Hurricane Center ${ }^{1}$. Wind data for 2008 were collected from the National Centers for Environmental Information Fort Lauderdale Airport station ${ }^{2}$, which is located approximately $3 \mathrm{~km}$ inshore and $10 \mathrm{~km}$ from the study sites; however, in 2009, a closer station was established on the ocean

\footnotetext{
${ }^{1}$ www.ncdc.noaa.gov

${ }^{2}$ www.nhc.noaa.gov
} 
approximately $6.5 \mathrm{~km}$ south of the study sites. Therefore, 20092016 were downloaded from the National Data Buoy Center station PVGF1-Port Everglades Channel, FL ${ }^{3}$. Rainfall data were obtained from the South Florida Water Management Districts Hollywood Station (2008-Oct 2014) and S36-RR Station (Nov. 2014-2016 $)$. Temperature $\left({ }^{\circ} \mathrm{C}\right)$ was recorded every $2 \mathrm{~h}$ using Onset Hobo Pendant ${ }^{\circledR}$ Temperature/Light loggers or TidbiT ${ }^{\circledR}$ v2 Temperature loggers attached to a permanent pin at each patch. Data were recorded from June 2008 at BCA and February 2010 at Scooter until the end of the study. Loggers were exchanged every 3-6 months. Unfortunately, a series of faulty loggers at Scooter resulted in missing data from 27 February 2014 to 10 August 2016.

\section{Data Analysis}

Plots in which A. cervicornis were never recorded during the duration of the study were not included in the analysis $(n=5$ for BCA). Data collected within each monitoring event by patch providing event means. For annual analyses, the three monitoring events completed during that calendar year were used; the TSI12 event was included in 2012 for a fourth event for that year. For the seasonal analyses, all years were used within each season; monitoring event TSI12 was included in the summer season (Winter $n=8$ events, Summer $n=10$, and Fall $n=8$ ).

Percent cover was estimated for each plot during each event and was used to calculate mean cover by patch. Trends in mean percent cover of living (PCL) A. cervicornis were analyzed using Time Series Analyses followed by decomposing the components and analyzing the decomposed trend component with a linear regression (R Core Team, 2017). Simple linear regressions were used to analyze the annual trend observed in PCL. One-way analysis of variance (ANOVA) was used to assess the differences in PCL between seasons. Post hoc comparisons were performed using Tukey's HSD tests. Kruskal-Wallis test by ranks was used to explore absolute change in PCL. When significant, multiple comparisons two-tailed post hoc tests were performed to determine significance between factor levels.

The total abundance of fragments, colonies, and masses in each individual plot were averaged by patch for each event, year, and season. The trends in mean abundance of fragments, colonies, and masses were analyzed using a Poisson regression for both between monitoring events and years. In addition, to determine differences in mean abundance and absolute change in abundance between seasons, Kruskal-Wallis test by ranks followed multiple comparisons two-tailed post hoc tests were used.

The presence of disease and predation was analyzed through the prevalence of plots with each condition. During each event, researchers documented the presence or absence of white disease, fireworm predation, damselfish predation, snail predation, and bleaching. A sum of the total number of plots with each condition was divided by the total number of plots with living A. cervicornis surveyed providing a prevalence for each condition for each event. Mean prevalence of plots with each condition was

${ }^{3}$ www.ndbc.noaa.gov

${ }^{4}$ my.sfwmd.gov calculated annually and seasonally. These data indicate how widespread each condition was at each patch. Prevalence of white disease was also calculated per plot by dividing the number of colonies or masses with disease by the total number of colonies or masses in each plot. Disease prevalence was analyzed using binomial (plot prevalence) and quasi-binomial (colony and mass prevalence) generalized linear models between monitoring event, years, and seasons. When the model identified significant factors, post hoc multiple comparisons with a Bonferroni correction were employed to define specific contrasts of factor levels.

The occurrence of white disease, fireworm predation, snail predation, and bleaching were summed by their occurrence on colonies or masses per plot. Mean number of occurrences of each condition per plot was calculated per monitoring event, year, and season. These data were analyzed using Kruskal-Wallis ANOVAs, and when significant, multiple comparisons two-tailed post hoc tests with a Bonferonni correction were performed.

Individual plot canopy height was used to calculate a mean canopy height per patch for each event. These data were analyzed across all events using linear regression analyses for both between monitoring events and annual changes.

\section{RESULTS}

Across the 8 years of the study, abundance and health of A. cervicornis were surveyed within 27 plots at BCA and 31 plots at Scooter, five plots at BCA never had A. cervicornis so were not included in the analysis. The center pin was not located for two plots at Scooter following the SM15 and F15 events because of $A$. cervicornis overgrowth and were not included following these events.

\section{Disturbance Events}

Tropical storm force winds, identified by the predicted area of the wind swath published by $\mathrm{NOAA}^{5}$, impacted southeast Florida during six named storm events (Table 1). Each storm had different conditions (temperature change, wave height, rainfall, and wind speed) and relate to the range of impacts at each patch. The passing of all storms, except Hurricane Sandy at BCA, resulted in mean PCL losses ranging from $1.5-50 \%$ for both patches. The largest PCL losses by area were $78 \mathrm{~m}^{2}$ for BCA during monitoring event WS09 and $116 \mathrm{~m}^{2}$ for Scooter during TSI12. Besides named storms, additional high energy periods during the study were identified by elevated mean daily wind speeds greater than the average sustained wind produced by a tropical storm, $12.78 \mathrm{kts}$ (Table 2). Additional losses of $>20 \%$ relative mean cover per patch were observed between events not associated with named storms at at least one patch during: WS10, F11, SM15, F15, WS16, and SM16.

\section{Cover Characteristics}

Percent cover of living decreased for both patches during the study, although only BCA had a significant, decreasing linear trend $\left[r^{2}=0.5013, F(3,20)=6.702, p<0.001\right.$; Scooter:

\footnotetext{
${ }^{5}$ http://www.nhc.noaa.gov
} 


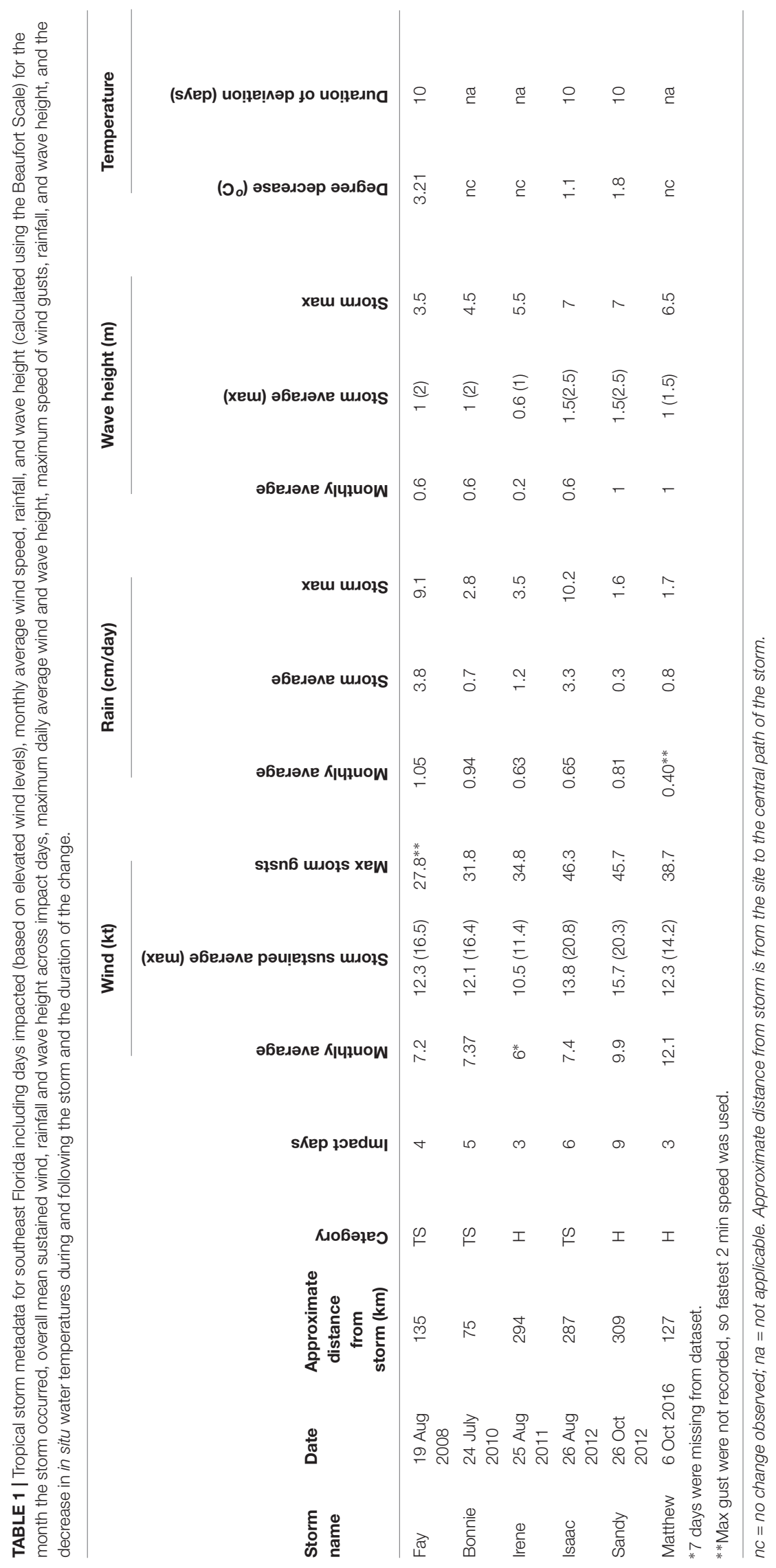


TABLE 2 | Number of days between monitoring events in which the wind speed was greater than the average wind speed (12.78 kts) observed in southeast Florida for the six tropical storms occurring during the study.

\begin{tabular}{|c|c|c|c|c|c|c|c|c|c|}
\hline & 2008 & 2009 & 2010 & 2011 & 2012 & 2013 & 2014 & 2015 & 2016 \\
\hline Fall to winter & na & 19 & 13 & 6 & 10 & 0 & 11 & 9 & 19 \\
\hline Winter to summer & na & na & 8 & 3 & 5 & 0 & 3 & 3 & 3 \\
\hline Summer to fall & na & 4 & 4 & 14 & 18 & 6 & 3 & 7 & 18 \\
\hline
\end{tabular}

na $=$ not enough data were available or no surveys were conducted (i.e., Winter and Fall, 2008).

$r^{2}=0.07924, F(3,20)=0.5738, p>0.05$; Figure 1). PCL within individual plots at BCA ranged from 0 to $70 \%$, with an overall study mean of $8.6 \pm 0.38 \%( \pm \mathrm{SE})$. PCL was greater at Scooter with an overall mean of $16.0 \pm 0.48 \%$ but had a similar range from 0 to $75 \%$. Fluctuation in cover was observed at both patches between monitoring events, years, and seasons with the greatest increases for both patches in 2013 and during the summer (Figures 1, 2). However, these gains were not enough to outweigh the total losses, and by area BCA experienced a net loss of $144 \mathrm{~m}^{2}$ of living A. cervicornis and Scooter $173 \mathrm{~m}^{2}$. The greatest PCL losses occurred following system-wide disturbance events such as tropical storms, hurricanes, or disease events (Table 1 and Figure 2).

The absolute change in mean PCL varied between monitoring events at both patches $\left(\mathrm{X}^{2}=106.88\right.$ and 174.28, $d f=24, p<0.001$ BCA and Scooter, respectively; Figure 2). The largest increases were observed from the winter to summer monitoring events where average increases in percent cover per plot were 1.4 and $1.9 \%$ at BCA and Scooter, respectively (Figure 2, yellow bars). When all years were pooled, 74 (BCA) and 68\% (Scooter) of the plots had a mean PCL increase during the summer monitoring events. A negative percent change in mean PCL was observed for a majority of the fall to winter and summer to fall monitoring periods. The magnitude of change was larger at Scooter for $60 \%$ of the monitoring events, and BCA and Scooter differed in gain or loss of tissue during six monitoring events (Figure 2).

Mean canopy height at BCA ranged from 38 to $55 \mathrm{~cm}$ and had an overall mean of $45.6 \pm 0.74 \mathrm{~cm}( \pm \mathrm{SE})$. Mean canopy height at Scooter ranged from 32 to $48 \mathrm{~cm}$ and had an overall mean of $43.2 \pm 0.50 \mathrm{~cm}$. Monitoring event had a significant effect on the absolute change in canopy height [BCA$r^{2}=0.1069, F(16,408)=3.051, p<0.001$; Scooter $-r^{2}=0.1907$, $F(16,470)=6.923, p<0.001]$. Canopy height varied across the study increasing during summer events and decreasing toward the end of the study, as indicated by a large portion of the plots having negative change in height for the final events (Figure 3).

\section{Species Census}

A total of 4,692 colonies were counted at BCA (density of $\left.0.18 \pm 0.01 \mathrm{col} / \mathrm{m}^{2}\right)$ and 11,894 at Scooter $\left(0.40 \pm 0.01 \mathrm{col} / \mathrm{m}^{2}\right)$

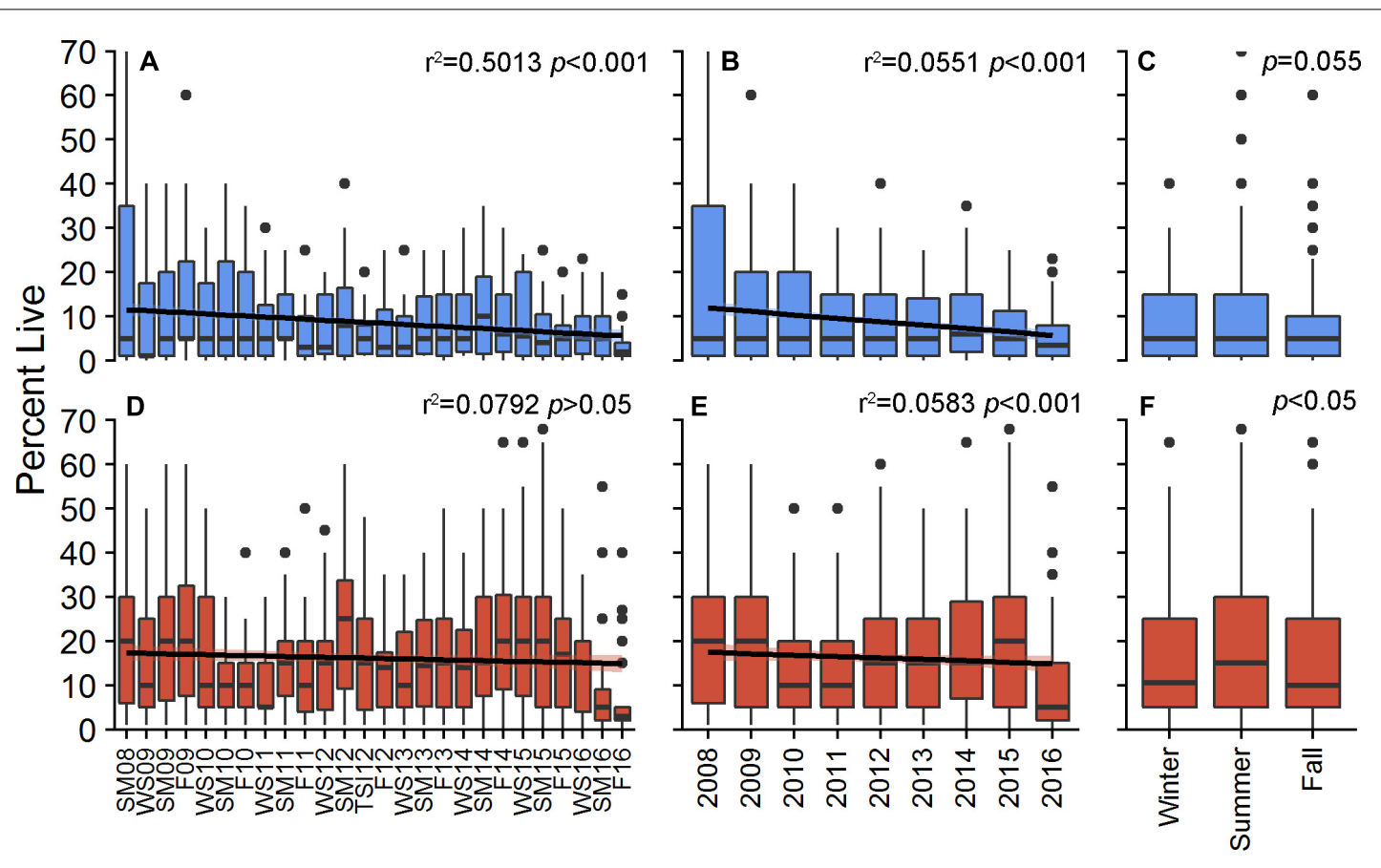

FIGURE 1 | Percent live cover of Acropora cervicornis per plot for BCA (blue) and Scooter (red) across monitoring periods (A,D), annually (B,E), and seasonally (C,F). Boxes represent the 25 and $75 \%$ quartiles with whiskers extending $1.5 *$ interquartile range, the line represents the median, and dots are considered outliers. 


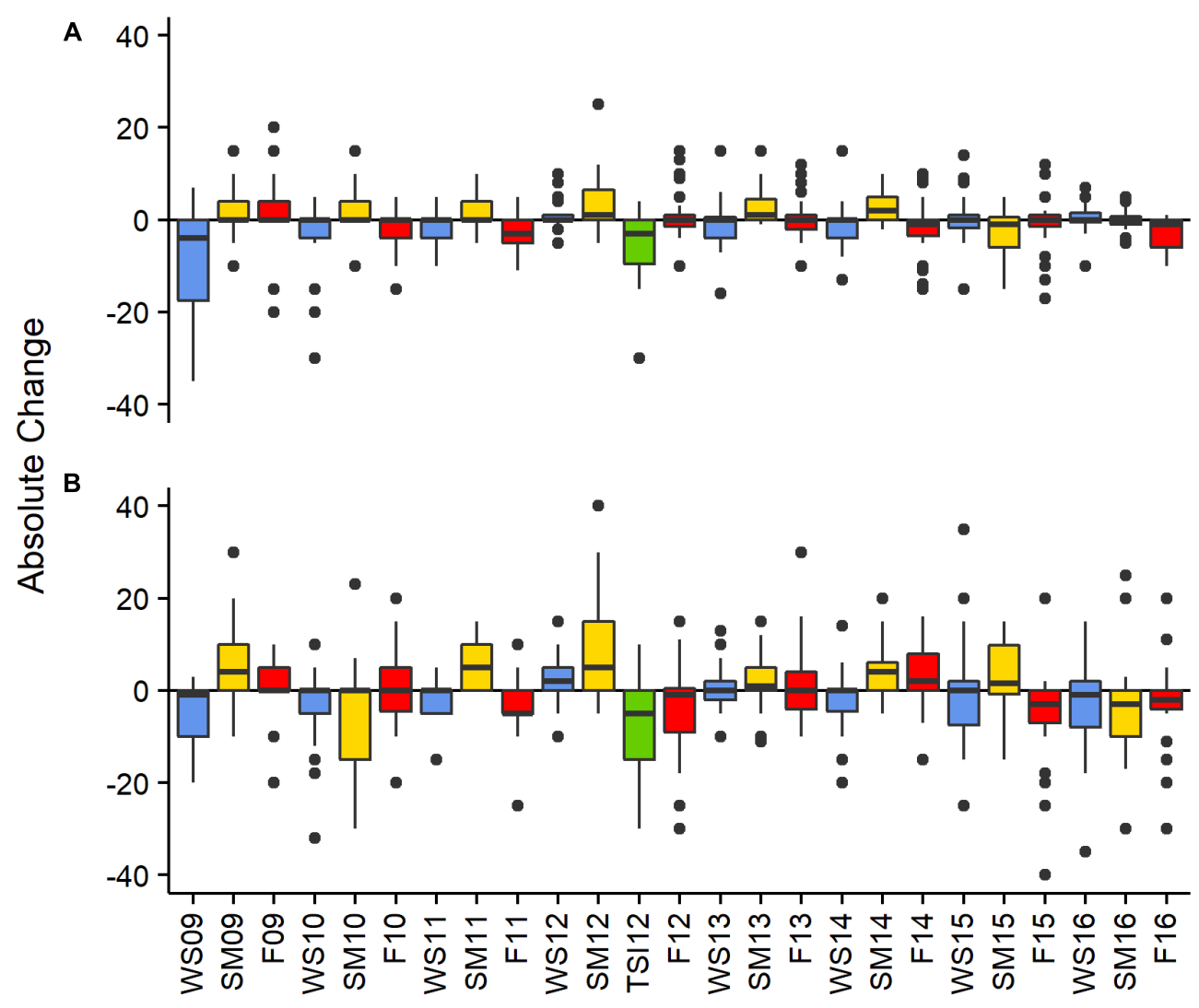

FIGURE 2 | Absolute change in percent cover between monitoring events by site BCA (A), Scooter (B). Colors represent seasonal changes from Fall to Winter-blue, Winter to Summer-yellow, and Summer to Fall-red, the green bar represents change in cover between the SM12 and the TSI12 monitoring events. Boxes represent the 25 and $75 \%$ quartiles with whiskers extending $1.5 *$ interquartile range, the line represents the median, and dots are considered outliers.

across the entire project. Mean colony abundance at Scooter exhibited a significant decreasing trend $(p<0.001)$, with moderate but significant seasonal variation $\left(\mathrm{X}^{2}=17.097\right.$, $p<0.001)$ whereas BCA remained relatively stable with only a few monitoring events having significant deviations from the mean $(p<0.001)$, but had no significant seasonal change $\left(\mathrm{X}^{2}=1.5795, p>0.05\right.$; Figure 4). On average, 70 colonies were lost at Scooter and 20 at BCA between each summer and fall monitoring event. Significant increases in mean colony abundance were observed in the summer at Scooter and the winter events at both patches $(p<0.05)$. The mean number of masses per plot for both patches was less than 4 (Figure 4). Counts of masses increased at Scooter from 2008 to 2010 and then remained stable. The most masses counted during one monitoring event were at Scooter with 119 masses during SM11. Significant seasonal changes in the abundance of masses were observed at Scooter, with greatest changes observed in the summer $(p<0.05)$.

Nearly 18,000 fragments were counted at the patches during the study. Total fragments counted per monitoring event ranged from 15 to 359 at BCA (plot average $=6.3 \pm 0.31$ fragments) and 80 to 1,313 at Scooter (17.6 \pm 0.73 fragments). Two major fragmentation events occurred at Scooter, WS10 and WS15, where total fragment counts were over 1,000. Four additional events (TSI12, F15, WS16, and F16) had counts 30\% over the patch mean. Fragment counts at BCA were highest during TSI12 and WS16 where total fragment counts were over 300. Differences were found between the annual means of fragment counts, with 2010, 2015, and 2016 as high years at Scooter and 2012 and 2016 at BCA. Mean fragment counts differed significantly between seasons (Figure 4); on average, there were 88 and 243 fewer fragments counted in the summer than in the previous winter at BCA and Scooter, respectively $(p<0.05)$.

\section{Condition Characteristics}

The most prevalent condition recorded for both patches, when all seasons and years were pooled, was fireworm predation followed by white disease, damselfish predation, snail predation, then bleaching. Two white diseases were observed at both patches, rapid tissue loss and white band disease, but because the distinction between them is uncertain, they were pooled as white disease for analyses. Similar annual and seasonal patterns were found between patches for all conditions, although prevalence rates were higher at Scooter for all conditions besides damselfish predation and bleaching. Overall mean prevalence of plots at BCA and Scooter, respectively, was $44.1 \pm 1.88$ SE\% and $72.0 \pm 1.6 \%$ for fireworm predation, $44.3 \pm 1.88$ and $66.6 \pm 1.68 \%$ for disease, $38.8 \pm 1.84$ and $33.2 \pm 1.67 \%$ for 


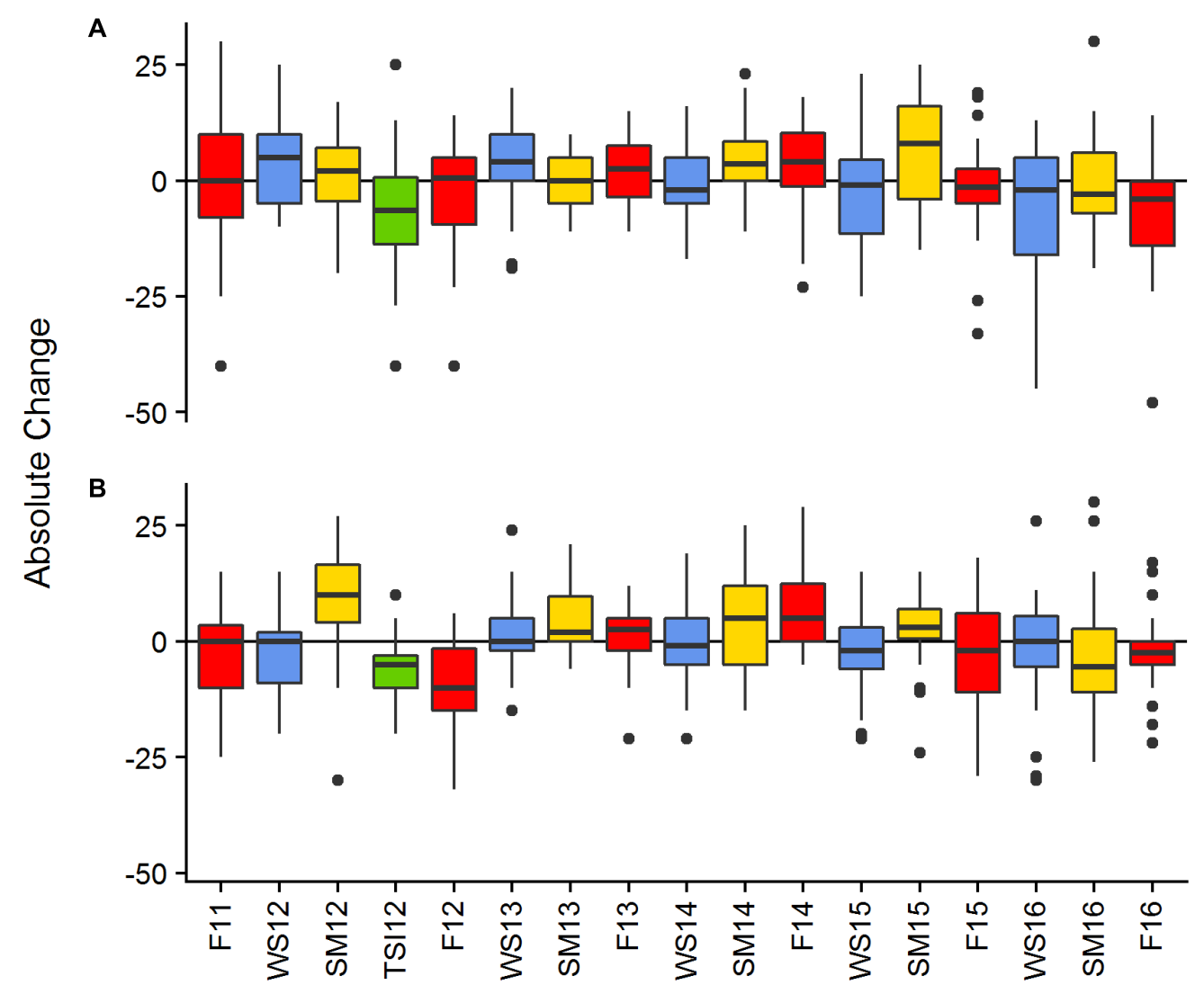

FIGURE 3 | Absolute change in canopy height between monitoring events of living Acropora cervicornis by site BCA (A), Scooter (B). Colors represent seasonal changes from Fall to Winter-blue, Winter to Summer-yellow, and Summer to Fall-red, the green bar represents change in cover between the SM12 and the TSI12 monitoring events. Boxes represent the 25 and 75\% quartiles with whiskers extending $1.5 *$ interquartile range, the line represents the median, and dots are considered outliers.

damselfish predation, $6.6 \pm 0.94$ and $17.9 \pm 1.36 \%$ for snail predation, and $6.2 \pm 0.91$ and $3.4 \pm 0.65 \%$ for bleaching.

Disease prevalence oscillated during the study, resulting in monitoring event, year, and season as significant factors in explaining prevalence of disease ( $\mathrm{glm},<0.001$; Figures 5, 6). The presence of disease increased at times when water temperatures were warmer and following disturbance events. The highest (or near highest) disease prevalence was observed during TSI12, and highest number of occurrences was during SM15 (Figures 5, 6). The year 2013 had the lowest mean maximum temperatures and significantly lower disease prevalence (Tukey, $p<0.01$ ) and occurrence counts. Disease was more widespread (present in more plots) at Scooter than BCA (Figures 5, 6), and when present, it was recorded as the primary cause of recent mortality $58 \pm 5$ and $57 \pm 4 \%$ of the time at BCA and Scooter, respectively. Overall mean prevalence of disease was higher on masses $36 \pm 2.5$ and $41 \pm 1.9 \%$ than on colonies $8 \pm 0.8$ and $7 \pm 0.5 \%$ for BCA $\left(\mathrm{X}^{2}=37.525, p<0.001\right)$ and Scooter $\left(\mathrm{X}^{2}=88.801, p<0.001\right)$, respectively. Nearly three times the occurrence counts occurred on masses than colonies (BCA: $\mathrm{X}^{2}=58.352, p<0.01$; Scooter: $\left.\mathrm{X}^{2}=121.4, p<0.001\right)$.

Fireworm predation affected $40-90 \%$ of the plots at Scooter with mean occurrence counts ranging from 1-10 recently preyed upon branch tips on colonies and 1-44 tips on masses per plot. Prevalence of plots with fireworm predation was lower at BCA, affecting fewer than $70 \%$ of the plots during any monitoring event. However, BCA had similar mean occurrence counts on colonies (1-8 tips) as Scooter, but much fewer on masses (214 tips). When present, it was recorded as the primary cause of mortality in $30 \pm 5$ and $41 \pm 4 \%$ plots on average for BCA and Scooter, respectively. Prevalence of fireworm predation was significantly higher in 2015 at both BCA and Scooter (Tukey, $p<0.001$ ) and significantly lower in 2013 at Scooter (Tukey, $p<0.001)$. Summer prevalence at Scooter was significantly higher than fall and spring (Tukey, $p<0.001$ ), and occurrence counts were the lowest in the fall on both colonies and masses (Figures 5, 6).

Snail predation was not observed at every monitoring event and increased significantly in prevalence toward the end of the study (2013-2016) at Scooter (glm, $p<0.01$ ). Prevalence was between 0 and $40 \%$ of plots at BCA and 0 $60 \%$ at Scooter. Although snail predation was affecting close to half of the plots when present, mean occurrence counts were less than three per plot, affecting masses significantly more than colonies (Kruskal-Wallis, $p<0.001$ ), and when present, was only the primary cause of mortality 

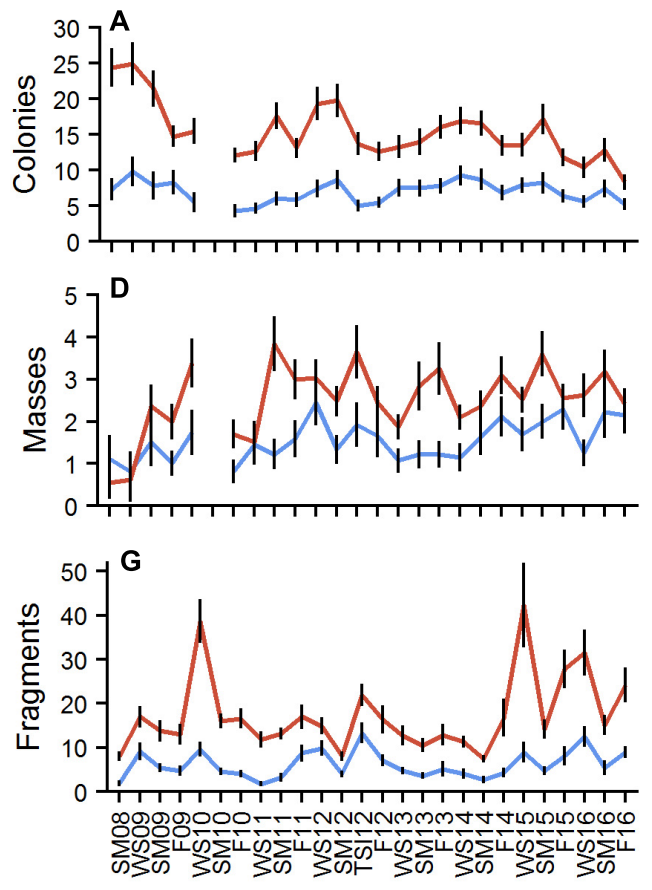
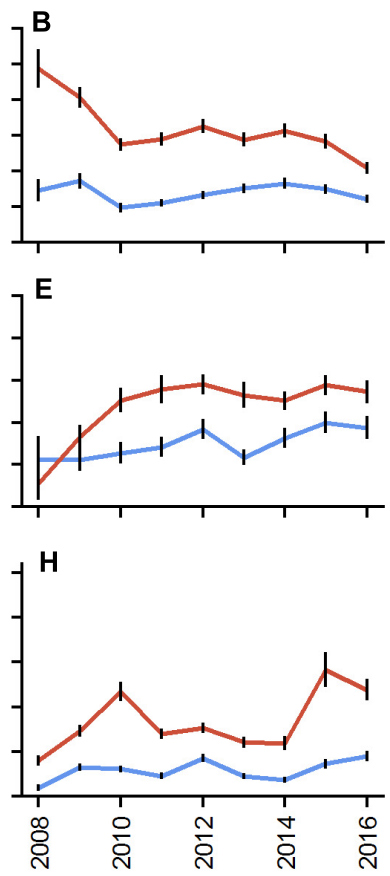
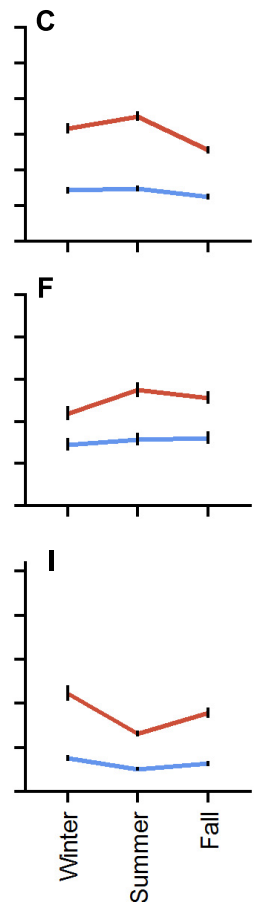

FIGURE $\mathbf{4}$ | Mean number of colonies (A-C), masses (D-F), and fragments (G-I) by plot for BCA (blue) and Scooter (red) by monitoring event (A,D,G), year (B,E,H), and season $\mathbf{( C , F , I ) . ~ E r r o r ~ b a r s ~ i n d i c a t e ~} \pm 1$ SE.

in $3 \pm 2$ and $12 \pm 4 \%$ of plots on average at BCA and Scooter, respectively.

Damselfish predation was present during all events and was more wide-spread at BCA than Scooter. It was the primary condition when present in $48 \pm 5$ and $34 \pm 5 \%$ of the plots on average at BCA and Scooter, respectively. Damselfish predation significantly increased during the study for Scooter (glm, $p<0.05$ ). No seasonal trends were detected in the prevalence of damselfish predation.

Bleaching was not present during all events and was significantly higher during the fall for BCA (Tukey, $p<0.001$ ) and summer for Scooter (Tukey, $p<0.01$ ). Bleaching was more prevalent at BCA than Scooter, affecting up to $70 \%$ of the plots (Figures 5, 6). Masses were more affected by bleaching than colonies.

\section{Temperature}

Monthly mean temperature increased during the study (Figure 7). The maximum monthly mean ranged between 29.2 and $30.8^{\circ} \mathrm{C}$. The warmest month was August for all years except 2008 when July was the warmest. Mean daily temperatures were above $31^{\circ} \mathrm{C}$ for 1 day in 2010,5 days in 2011, 10 days in 2014, and 11 days in 2015. Minimum monthly mean increased during the study, ranging from a low in 2009 of $21.5^{\circ} \mathrm{C}$ to a high in 2014 of $23.9^{\circ} \mathrm{C}$. From January 2012 through 2016, only 5 days fell below $22^{\circ} \mathrm{C}$, whereas from January 2009 through December 2011 there were 83 days below $22^{\circ} \mathrm{C}$.

\section{DISCUSSION}

Presented here is a portion of the one of the longest continuous demographic-based monitoring datasets, specifically targeting long-term monitoring of the threatened coral A. cervicornis. Published studies on the demography of this species are either sporadic across many years, missing short-term temporal changes and drivers of mortality and recovery, or cover only a few years, missing long-term trends and factors affecting life history characteristics such as impacts from destructive events that may not occur during the time frame of the study. This study included 8 years of observations of two high density populations and documented temporal variation in: PCL, fragment, colony, and mass abundance, and prevalence and occurrence of disease and predation. Environmental disturbances and disease caused significant decreases in PCL and total abundance of colonies. Disease was constantly present and increased during the summer, following Tropical Storms, and on masses. Predation by fireworms, snails, and damselfish caused minimal mortality when compared to disease, but their chronic presence is concerning for species growth, reproduction, and possible transmitter of disease. Unfortunately, the overall health of the two patches deteriorated significantly over the 8 years of this study. Mean cover of living A. cervicornis decreased by over $50 \%$ at both patches (17-3\% BCA; 26-7\% Scooter) due to the increasing prevalence of predation and disease and the high frequency of disturbances such as tropical storms, hurricanes, high energy events, and a widespread disease event affecting the Florida Reef Tract (Precht et al., 2016). 


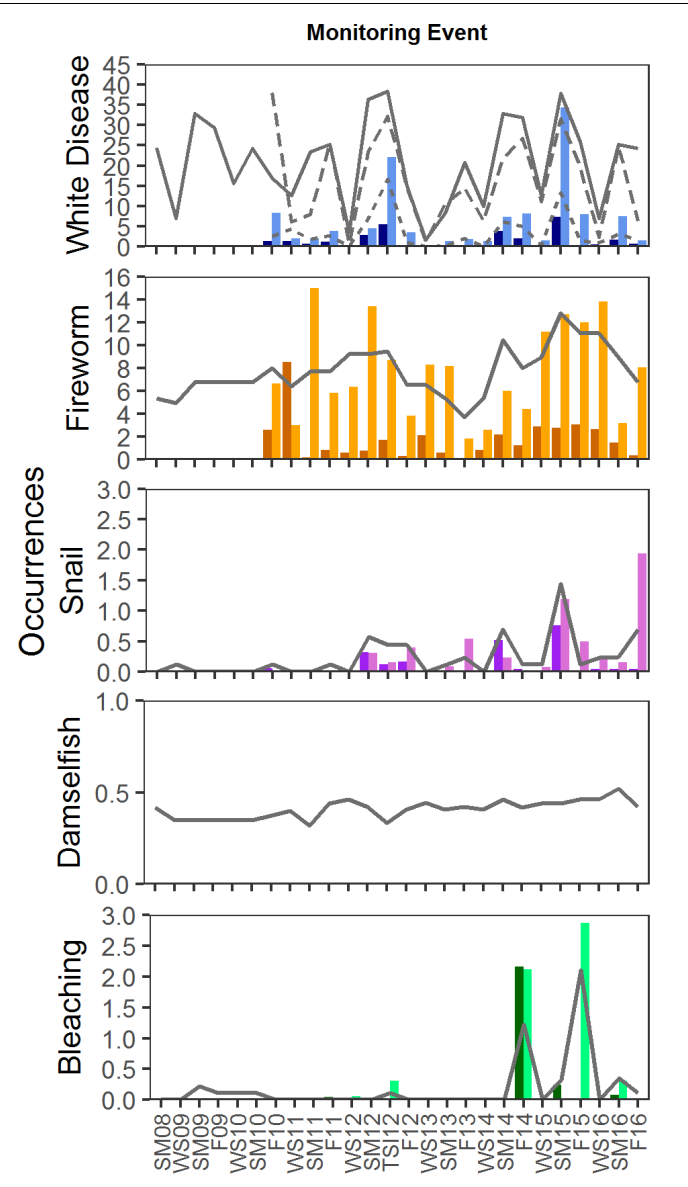

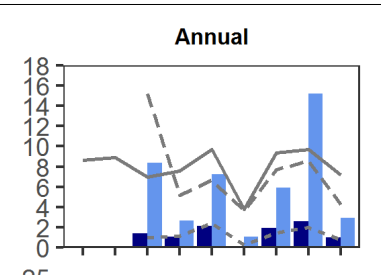
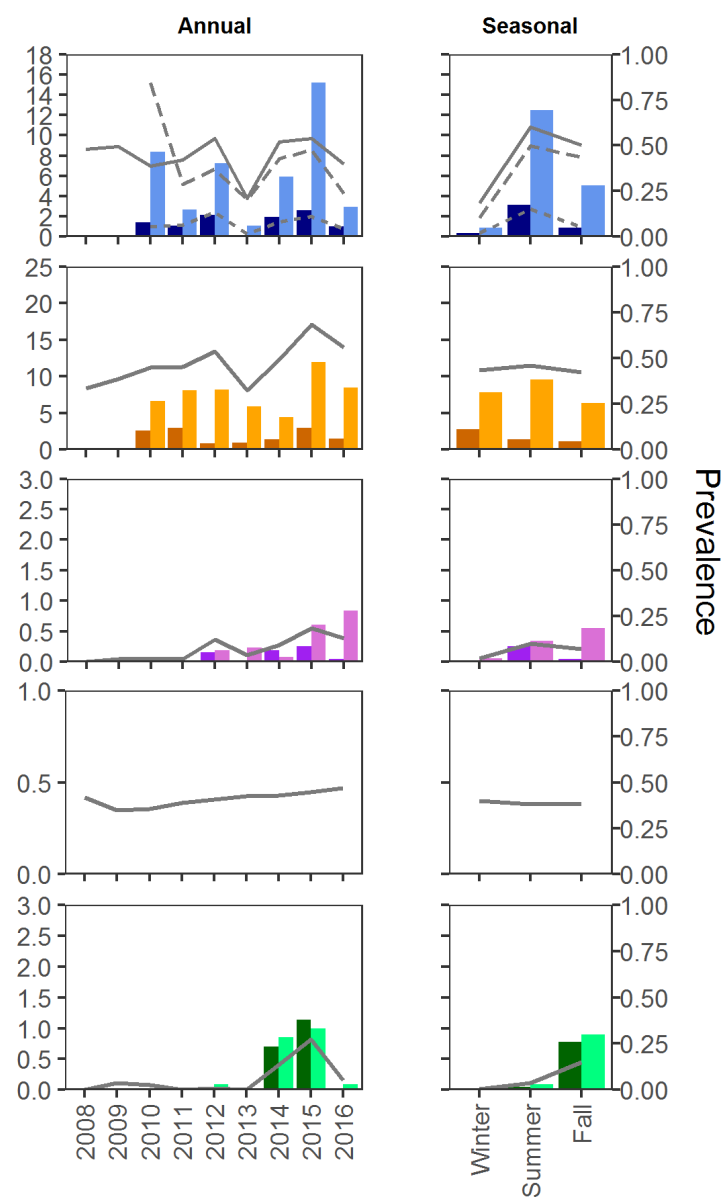

FIGURE 5 | Mean prevalence and occurrence of disease, predation, and bleaching by plot at BCA. Prevalence is indicated by the lines on each graph; solid lines represent prevalence of plots with condition. For disease, dotted and dashed lines represent prevalence on colonies and masses, respectively. Occurrences of each condition were counted on colonies (dark bars) and masses (light bars). Occurrences were not counted for Damselfish predation.

Disturbances during the study disrupted the demography of A. cervicornis. During these periods, we documented an increase in disease and predation (typically during the summer) and an increase in fragmentation (during the fall and winter). In fact, the two largest fragmentation events were subsequently followed by an increase in disease prevalence. Exposed skeleton from fragmentation could increase disease susceptibility (Knowlton et al., 1981). In the best-case scenario, we would have expected to see a shift from fragment to colonies and eventually to masses across the study. However, our data indicate that fragment survival and attachment rate may be very low, but similar to what has been previously reported (Highsmith et al., 1980; Knowlton et al., 1981, 1990; Heyward and Collins, 1985; Dollar and Tribble, 1993; Miller et al., 2016a). These rates were not enough to replace the loss of tissue caused by disturbance events. The frequency of disturbance events varied between years; however, during years of few or no disturbances such as 2013, both patches exhibited signs of recovery with increased PCL. This relatively mild year, with lowest maximum mean water temperatures, average wind speeds, and above average rainfall, resulted in the lowest prevalence of both disease and fireworm predation at both patches. This year could be a model year for conditions that allowed for population recovery.

Coral diseases are known to peak when there have been significant or prolonged changes in water temperature, sedimentation, pollution, predator lesions, or for unexplainable reasons (Harvell et al., 1999, 2007). Our data indicate that the diseases affecting A. cervicornis, while continuously observed in background levels, may also be exacerbated by increased water temperatures and disturbance events. It is also likely that fireworms and snails may be acting as vectors or reservoirs for pathogens as there is a relationship between the prevalence of disease and predation at both sites (Williams and Miller, 2005; Gignoux-Wolfsohn et al., 2012; Miller et al., 2014b; Bright et al., 2015). Above average air temperatures from May through mid-October 2009 caused SST to remain high through October, resulting in over 80 days at or above $30^{\circ} \mathrm{C}$. This increased duration of warmer waters preceded one of the highest prevalence of disease (70-94\% of plots) and predation (80-90\% of plots) recorded for this study, and prevalence remained high for the next two monitoring events, leading to a major decrease in live tissue at Scooter $\left(-121 \mathrm{~m}^{2}\right)$. Live tissue at BCA at this time 

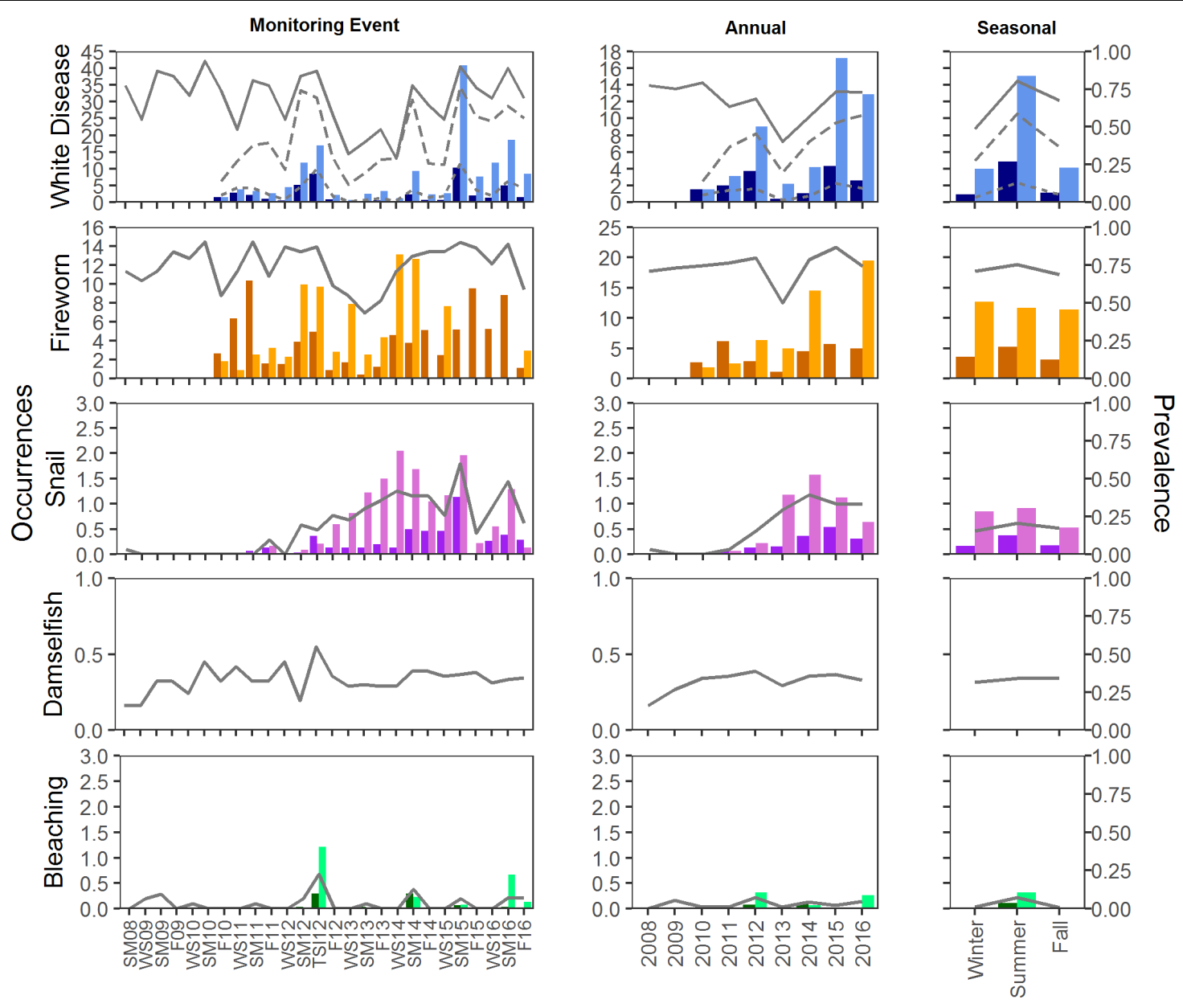

FIGURE 6 | Mean prevalence and occurrence of disease, predation, and bleaching by plot at Scooter. Prevalence is indicated by the lines on each graph; solid lines represent prevalence of plots with condition. For disease, dotted and dashed lines represent prevalence on colonies and masses, respectively. Occurrences of each condition were counted on colonies (dark bars) and masses (light bars). Occurrences were not counted for Damselfish predation.

also decreased but only slightly $\left(-20 \mathrm{~m}^{2}\right)$, and the prevalence of disease and predation were elevated but lower than Scooter.

The occurrence of disease was significantly higher in 2015 during a widespread disease event affecting the entire Florida Reef Tract (Miller et al., 2016a; Precht et al., 2016). These two patches of A. cervicornis were not spared from this outbreak, but were affected on different time scales. Increased presence of disease was maintained at Scooter into the following year, and while there was a decrease in occurrences, prevalence indicated that disease was still present across the entire patch at greater than average prevalence rates. BCA however, had a slight reprieve from disease and a small increase in percent cover, until Hurricane Matthew passed by in October 2016, further reducing PCL at both sites. Prevalence of disease may have been lower at BCA simply due to the sparseness of tissue remaining.

Predation by fireworms and snails varied radically during the study by years, seasons, and sites. The variability was similar to what Miller et al. (2014b) reported across 2 years at multiple sites. While prevalence levels were chronic, the mean tissue lost per colony has been described as $3 \%$ (Goergen et al., unpublished). Fireworms typically feed on the live branch tips of colonies, removing the growing end, and stunting branch growth. Regrowth and repair over the consumed area is unlikely (Berkle, 2004; Miller et al., 2014b). Increased occurrence and prevalence of fireworm and snail predation toward the end of the study could be severely damaging for the future growth of the species because predation may become more focused due to the lack of tissue available, leading to the removal of more growth tips from the same colonies. Moreover, fireworms have been a proven vector of a bleaching pathogen (Sussman et al., 2003), which is of great concern because colonies with predation lesions may be more likely to become diseased (Miller et al., 2014b) and both fireworms and snails have been associated with increased disease prevalence (Knowlton et al., 1990; Miller et al., 2014b; Bright et al., 2016). Therefore, it may be advantageous to manage both snail and fireworm populations to increase the health and growth of A. cervicornis.

Not only do the presence of disease and predation have a spatial and temporal component, they were also variable 


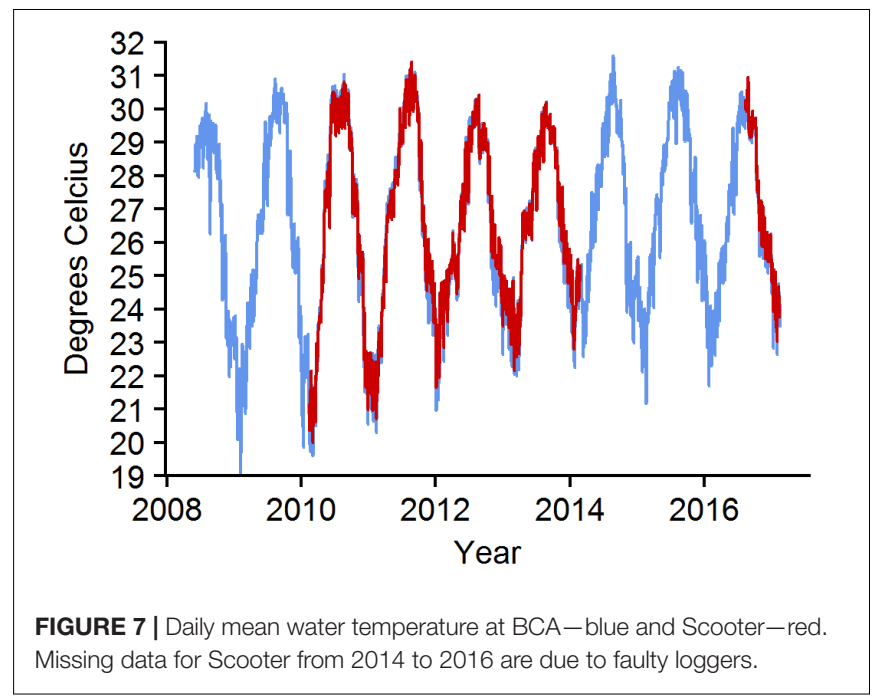

across different life history stages, affecting masses more than colonies. The prevalence of disease for this study ranged from 0 to $37 \%$ on colonies (mean approximately $7 \%$ ) which was similar to previous reports across the species' range (Lirman et al., 2010; Miller et al., 2014a; Goergen et al., unpublished). However, on masses (what others may consider large colonies, thickets, or patches) prevalence was higher, with a range of 2$84 \%$ (mean 38\%), than previously reported (Vargas-Ángel et al., 2003; Ladd et al., 2016; Goergen and Gilliam, 2018). Because of this discrepancy, high density patches may not be able to persist long-term under modern day conditions. While healthy populations do still exist (Walker, 2017), the loss of cover may be a cyclical event linked to population growth (density) and age. While we were unable to age the patches anecdotal observations of patch structure and successional stages such as height and extant of old dead structure and abundance and size of Agaricia spp. colonies on dead structure, indicate that BCA is older and experienced cover decline prior to Scooter. Therefore, as populations grow and potentially expand into high density patches, disease and predation are likely to increase after some time, causing substantial mortality subsequently weakening the skeleton and increasing the likelihood of fragmentation. This process could be detrimental to the persistence of the dense patches unless the fragmentation of a patch can shift to an alternate stable state such as isolated colonies; however, we found very low reattachment success of loose fragments. On the other hand, signs of recovery were present in this study in 2013 when predation and disease prevalence were minimal, maximum water temperatures were lower, and there were only a few days of elevated winds. Unfortunately, reducing water temperatures and wind speeds is out of our direct control; however, active management of predators may be a feasible task. This may be even more prudent in high density areas where disease is more prevalent. Because we still do not know the etiology and transmission mechanisms of these diseases (spreading could be occurring through water movement or fish) by abating disease where it is most abundant will benefit the rest of the marine community.
Extreme changes in cover may not indicate a total loss of A. cervicornis tissue at the site. Its high frequency of fragmentation and dislodgement (Goergen et al., unpublished) and fast growth rate allow for fast propagation across sites if conditions are conducive (Highsmith et al., 1980). In previous research, we have shown that the centroids of the densest portions of these patches are indeed shifting (Walker et al., 2012). This shift in live cover is evident in the monitoring plots surrounding the high density areas in the direction of the centroid shift. However, increases in cover in these plots is very minimal (less than $5 \%$ ) and is in no way equivalent to what was lost in the other plots. In addition, it was most common for plots to decrease in live cover and simultaneously increase in dead skeleton, indicating high mortality and not extreme movement that could support the notion that the population is just shifting spatially. However, there is evidence that propagation is still occurring through colony fragmentation and dislodgement. Propagation through fragmentation has the potential to support the existence of this species in low levels but gains do not keep up with the mortality observed. Despite there being evidence of reef recovery from the propagation of A. cervicornis through fragmentation in the Florida Keys in the 1970s (Gilmore and Hall, 1976; Shinn, 1976), current ocean conditions and the increase in frequency of disturbance events will make it difficult for A. cervicornis to recover naturally. Population enhancement by way of outplanting colonies in low density aggregations from nurseries could have a positive effect on this species' long-term sustainability while larger environmental issues are tackled (Miller et al., 2016b; Goergen and Gilliam, 2018; Hughes et al., 2018).

Overall, our results confirm that A. cervicornis is greatly affected by extreme environmental conditions, disease, and predation. Unfortunately, our data also indicate that prevalence of disease, predation, and fragmentation are increasing and having an even greater detrimental effect on the long-term persistence of this species. As oceans continue to warm (Hughes et al., 2018), warm water driven factors such as bleaching, disease, and predation will increase in frequency and likely intensity. Without time for recovery and growth between these major events, this species will not recover naturally. Of concern is the relationship between disease and predation prevalence and occurrences on masses, which is implying density driven mortality and indicating a cyclical component to the existence of the species. As populations become denser and age, disease and predation become more widespread causing populations to decline to remnant patches of isolated colonies. Furthermore, under modern day reef condition and the frequent occurrences of storms and elevated winds, paired with seasonal and sometimes chronic disease and chronic predation, the ability for a population to grow into these large patches may be difficult. However, these populations are of upmost importance to the continued existence of the species providing an abundance of larvae during spawning and through fragmentation these populations are likely a source to local expansion through propagation of fragments. Therefore, we suggest specific management actions such as the management of predator populations; this may not only lead to improved growth of colonies by reducing the number of damaged growth ends, but could also lead to a reduction in 
disease due to their abilities to be vectors of pathogens. This may be even more prudent in high density areas where disease is more prevalent, because the etiology of these diseases is still unknown, and they could also be spreading by water movement or fish, by abating disease where it is most abundant would benefit the rest of the marine community. Furthermore, supporting population enhancement by advising practitioners to outplant at lower densities would also improve the health and longevity of A. cervicornis. While colonies may eventually grow together, outplanting them further apart provides more time for growth and healthy colonies to spread across the reef.

\section{AUTHOR CONTRIBUTIONS}

EG, DG, AM, and BW conceived and designed the research, performed the experiments, and edited the manuscript. EG analyzed the data and wrote the manuscript.

\section{FUNDING}

This work was made possible through the support of the National Coral Reef Institute by an award made to

\section{REFERENCES}

Acropora Biological Review Team (2005). Atlantic Acropora status review document. Seattle, WA: Report to National Marine Fisheries Service, Southeast Regional Office.

Adey, W. H., and Burke, R. B. (1977). "Holocene bioherms of lesser antillesgeologic control of development," in Reef and Related Carbonates-Ecology and Sedimentology, eds S. H. Frost, M. P. Weiss, and J. B. Saunders (Tulsa, OK: American Association of Petroleum Geologists), 67-81.

Antonius, A. (1977). "Coral Mortality in reefs: a problem for science and management," in Proceedings of the 3rd International Coral Reef Symposium, Miami, FL, 617-623.

Aronson, R. B., Bruckner, A. W., Moore, J., Precht, W. F., and Weil, E. (2008). IUCN Red List of threatened species: Acropora cervicornis. Available at: http: //www.iucnredlist.org [accessed June 28, 2013].

Aronson, R. B., and Precht, W. F. (2001). White-band disease and the changing face of Caribbean coral reefs. Hydrobiologia 460, 25-38. doi: 10.1023/A: 1013103928980

Berkle, M. E. (2004). Population Densities and Feeding Behavior of the Amphinomid polychaete, Hermodice carunculata, in Acropora cervicornis Assemblages in Southeastern Florida. master's thesis, Nova Southeastern University, Davie, FL.

Bright, A. J., Cameron, C. M., and Miller, M. W. (2015). Enhanced susceptibility to predation in corals of compromised condition. PeerJ 3:e1239. doi: 10.7717/ peerj.1239

Bright, A. J., Rogers, C. S., Brandt, M. E., Muller, E., and Smith, T. B. (2016). Disease prevalence and snail predation associated with swell-generated damage on the threatened coral, Acropora palmata (Lamarck). Front. Mar. Sci. 3:77. doi: 10.3389/fmars.2016.00077

Bruckner, A. W. (2002). Proceedings of the Caribbean Acropora workshop: Potential Application of the U.S. Endangered Species Act as a Conservation Strategy. Silver Spring, MD: NOAA Technical Memorandum NMFS-OPR-24, 199.

Busch, J., Greer, L., Harbor, D., Wirth, K., Lescinsky, H., Curran, H. A., et al. (2016). Quantifying exceptionally large populations of Acropora spp. corals off Belize using sub-meter satellite imagery classification. Bull. Mar. Sci. 92, 265-283. doi: $10.5343 / \mathrm{bms} .2015 .1038$

Bythell, J. C., Gladfelter, E. H., and Bythell, M. (1993). Chronic and catastrophic natural mortality of three comon Caribbean reef corals. Coral Reefs 12, 143-152. doi: $10.1007 / \mathrm{BF} 00334474$
Nova Southeastern University from National Oceanic and Atmospheric Administration Coastal Ocean Program Award Number NA03NOS4260046, National Oceanic and Atmospheric Administration Award Number NA10NMF4720029 to the Florida Fish and Wildlife Conservation Commission, and Nova Southeastern University Presidents Faculty Research and Development Grant.

\section{ACKNOWLEDGMENTS}

We thank all the past, present, and honorary students of the Nova Southeastern University Coral Reef Restoration, Assessment, and Monitoring Lab for assisting in data collection. A special thanks goes to Dale Goergen for his never ending help and determination in designing and perfecting the figures in $\mathrm{R}$ and E.A. Goergen's Ph.D. committee for their thoughtful comments and critiques during project planning and dissertation reviews. This manuscript was submitted in partial fulfilment for E.A. Goergen's degree of Doctorate of Philosophy at Nova Southeastern University Halmos College of Natural Sciences and Oceanography.

Bythell, J. C., Gladfelter, E. H., Gladfelter, W., French, K., and Hillis, Z. (1989). "Buck island reef national monument-changes in modern reef community structure since 1976," in Terrestrial and Marine Geology of St. Croix, U.S. Virgin Islands, ed. D. Hubbard (St. Croix: West Indies Lab. Spec. Pub 8 Fairleigh Dickenson University), 145-153.

D'Antonio, N. L., Gilliam, D. S., and Walker, B. K. (2016). Investigating the spatial distribution and effects of nearshore topography on Acropora cervicornis abundance in Southeast Florida. PeerJ 4:e2473. doi: 10.7717/peerj.2473

Davis, G. E. (1982). A century of natural change in coral distribution at the dry tortugas: a comparison of reef maps from 1881-1976. Bull. Mar. Sci. 32, 608-623.

Dollar, S., and Tribble, G. (1993). Recurrent storm disturbance and recovery: a long-term study of coral communities in Hawaii. Coral Reefs 12, 223-233. doi: 10.1007/BF00334481

Gignoux-Wolfsohn, S. A., Marks, C. J., and Vollmer, S. V. (2012). White band disease transmission in the threatened coral, Acropora cervicornis. Sci. Rep. 2:804. doi: 10.1038/srep00804

Gilmore, M. D., and Hall, E. R. (1976). Life history, growth habitats and constructional roles of Acropora cervicornis in the patch reef environment. J. Sedimen. Petrol. 46, 519-522.

Gladfelter, W. (1982). White-band disease in Acropora palmata: implications for the structure and growth of shallow reefs. Bull. Mar. Sci. 32, 639-643.

Goergen, E. A., and Gilliam, D. S. (2018). Outplanting technique, host genotype, and site affect the initial success of outplanted Acropora cervicornis. PeerJ 6:e4433. doi: $10.7717 /$ peerj.4433

Goreau, N. I., and Goreau, T. F. (1973). Coral reef project-papers in memory of Dr. Thomas F. Goreau. Bull. Mar. Sci. 23, 399-464.

Goreau, T. F. (1959). The ecology of Jamaican coral reefs I. Species composition and zonation. Ecology 40, 67-90. doi: 10.2307/1929924

Grober-Dunsmore, R., Bonito, V., and Frazer, T. K. (2006). Potential inhibitors to recovery of Acropora palmata populations in St. John, US Virgin Islands. Mar. Ecol. Prog. Ser. 321, 123-132. doi: 10.3354/meps321123

Harvell, C. D., Kim, K., Burkholder, J. M., Colwell, R. R., Epstein, P. R., Grimes, D. J., et al. (1999). Emerging marine diseases-climate links and anthropogenic factors. Science 285, 1505-1510. doi: 10.1126/science.285.5433.1505

Harvell, D., Jordán-Dahlgren, E., Merkel, S., Rosenberg, E., Raymundo, L., Smith, G., et al. (2007). Coral disease, environmental drivers, and the 
balance between coral and microbial associates. Oceanography 20, 172-195. doi: 10.5670/oceanog.2007.91

Heyward, A., and Collins, J. (1985). Fragmentation in Montipora ramosa: the genet and ramet concept applied to a reef coral. Coral Reefs 4, 35-40. doi: 10.1007/BF00302202

Highsmith, R. C., Riggs, A. C., and D’Antonio, C. M. (1980). Survival of hurricanegenerated coral fragments and a disturbance model of reef calcification/growth rates. Oecologia 46, 322-329. doi: 10.1007/BF00346259

Hughes, T. P., Anderson, K. D., Connolly, S. R., Heron, S. F., Kerry, J. T., Lough, J. M., et al. (2018). Spatial and temporal patterns of mass bleaching of corals in the Anthropocene. Science 359:80. doi: 10.1126/science.aan8048

Keck, J., Houston, R. S., Purkis, S., and Riegl, B. M. (2005). Unexpectedly high cover of Acropora cervicornis on offshore reefs in Roatán (Honduras). Coral Reefs 24:509. doi: 10.1007/s00338-005-0502-506

Knowlton, N., Lang, J. C., and Keller, B. D. (1990). Case study of natural population collapse: post-hurricane predation on Jamaican Staghorn coral. Smithson. Contribut. Mar. Sci. 36, 1-25. doi: 10.5479/si.01960768.31.1

Knowlton, N., Lang, J. C., Rooney, M. C., and Clifford, P. (1981). Evidence for delayed mortality in hurricane damaged Jamaican staghorn corals. Nature 294, 251-252. doi: 10.1038/294251a0

Ladd, M. C., Shantz, A. A., Nedimyer, K., and Burkepile, D. E. (2016). Density dependence drives habitat production and survivorship of Acropora cervicornis used for restoration on a Caribbean coral reef. Front. Mar. Sci. 3:261. doi: $10.3389 /$ fmars.2016.00261

Lirman, D., Bowden-Kerby, A., Schopmeyer, S., Huntington, B., Thyberg, T., Gough, M., et al. (2010). A window to the past: documenting the status of one of the last remaining 'megapopulations' of the threatened staghorn coral Acropora cervicornis in the Dominican Republic. Aquat. Conserv. 20, 773-781. doi: $10.1002 /$ aqc. 1146

Mercado-Molina, A., Ruiz-Diaz, C., Pérez, M., Rodríguez-Barreras, R., and Sabat, A. (2015). Demography of the threatened coral Acropora cervicornis: implications for its management and conservation. Coral Reefs 34, 1113-1124. doi: 10.1007/s00338-015-1341-1348

Miller, M. W., Karazsia, J., Groves, C. E., Griffin, S., Moore, T., Wilber, P., et al. (2016a). Detecting sedimentation impacts to coral reefs resulting from dredging the Port of Miami. Florida USA. PeerJ 4:e2711. doi: 10.7717/peerj. 2711

Miller, M. W., Kerr, K., and Williams, D. E. (2016b). Reef-scale trends in Florida Acropora spp. abundance and the effects of population enhancement. PeerJ 4:e2523. doi: $10.7717 /$ peerj.2523

Miller, M. W., Lohr, K. E., Cameron, C. M., Williams, D. E., and Peters, E. C. (2014a). Disease dynamics and potential mitigation among restored and wild staghorn coral, Acropora cervicornis. PeerJ 2:e541. doi: 10.7717/peerj. 541

Miller, M. W, Marmet, C., Cameron, C., and Williams, D. (2014b). Prevalence, consequences, and mitigation of fireworm predation on endangered staghorn coral. Mar. Ecol. Prog. Ser. 516, 187-194. doi: 10.3354/meps10996

National Marine Fisheries Service (2006). Endangered and threatened species: final listing determinations for elkhorn coral and staghorn coral. Fed. Reg. 71, $26852-26872$.
Neigell, J. E., and Avise, J. C. (1983). Clonal diversity and population structure in a reef-building coral, Acropora cervicornis: self recognition analysis and demographic interpretation. Evolution 37, 437-453.

Precht, W. F., Gintert, B. E., Robbart, M. L., Fura, R., and van Woesik, R. (2016). Unprecedented disease-related coral mortality in southeastern Florida. Sci. Rep. 6:31374. doi: 10.1038/srep31374

R Core Team (2017). R: A Language and Environment for Statistical Computing. Vienna: R Foundation for Statistical Computing.

Schopmeyer, S. A., Lirman, D., Bartels, E., Byrne, J., Gilliam, D. S., Hunt, J., et al. (2012). In situ coral nurseries serve as genetic repositories for coral reef restoration after an extreme cold-water event. Restor. Ecol. 20, 696-703. doi: 10.1111/j.1526-100X.2011.00836.x

Shinn, E. A. (1976). Coral reef recovery in Florida and the Persian Gulf. Environ. Geol. 1, 241-254. doi: 10.1007/BF02407510

Sussman, M., Loya, Y., Fine, M., and Rosenberg, E. (2003). The marine fireworm Hermodice carunculata is a winter reservoir and spring-summer vector for the coral-bleaching pathogen Vibrio shiloi. Environ. Microbiol. 5, 250-255. doi: 10.1046/j.1462-2920.2003.00424.x

Vargas-Ángel, B., Thomas, J. D., and Hoke, S. M. (2003). High-latitude Acropora cervicornis thickets off Fort Lauderdale, Florida, USA. Coral Reefs 22, 465-473. doi: 10.1007/s00338-003-0336-z

Walker, B. K. (2017). Characterize the condition of previously known and newly identified large dense Acropora cervicornis patches in southeast Florida. Florida Department Environ. Protect. Coral Reef Conserv. Program. 1-76.

Walker, B. K., Larson, E. A., Moulding, A. L., and Gilliam, D. S. (2012). Small-scale mapping of indeterminate arborescent acroporid coral (Acropora cervicornis) patches. Coral Reefs 31, 885-894. doi: 10.1007/s00338-0120910-913

Williams, D. E., and Miller, M. W. (2005). Coral disease outbreak: pattern, prevalence and transmission in Acropora cervicornis. Mar. Ecol. Prog. Ser. 301, 119-128. doi: 10.3354/meps301119

Williams, D. E., and Miller, M. W. (2006). "Importance of disease and predation to the growth and survivorship of juvenile Acropora palmata and A. cervicornis: a demographic approach," in Proceedings of the 10th International Coral Reef Symposium, Okinawa, 1096-1104.

Williams, D. E., Miller, M. W., and Kramer, K. L. (2006). Demographic Monitoring Protocols for Threatened Caribbean Acropora spp. corals. Silver Spring, MD: NOAA Technical Memorandum NMFS-SEFSC-543,

Conflict of Interest Statement: The authors declare that the research was conducted in the absence of any commercial or financial relationships that could be construed as a potential conflict of interest.

Copyright (C) 2019 Goergen, Moulding, Walker and Gilliam. This is an open-access article distributed under the terms of the Creative Commons Attribution License (CC BY). The use, distribution or reproduction in other forums is permitted, provided the original author(s) and the copyright owner(s) are credited and that the original publication in this journal is cited, in accordance with accepted academic practice. No use, distribution or reproduction is permitted which does not comply with these terms. 